IBT Journal of Business Studies

Volume 15(1), 2019, 84-94

\title{
The Impact of CCC and WC on The Profitability of KMI-30 Index
}

\author{
Samina Riaz ${ }^{*}$ \\ Athar Iqbal ${ }^{2}$ \\ M Irfan $\mathrm{Khan}^{3}$
}

\begin{abstract}
This research purpose is to investigate the impact of $\mathrm{WC}$ and $\mathrm{CCC}$ on prosperity of the companies, listed in KMI-30 Index. For this research data was gathered from firm's annual reports. Data of 30companies listed in KMI-30 Index was collected over the period of 2010 till 2014. Data was collected to check significance of ROE, Tobin's Q, and ROA. To analyze these variables regression analysis was used to measure the impact on dependent variable through independent variables. The study concluded that cash conversion cycle and debt to assets ratio were most significant variable on the dependent variables i.e. ROA, Tobin's Q and ROE. It was recommended to the companies of listed in the KMI-30 to maintain the CCC at their minimum level or in lines with the industry norms, so they can avoid the liquidity problem along with the reduce the shortfall of cash requirement which were needed to smoothly run the operations of the companies.
\end{abstract}

Keywords: KMI-30, Tobin's Q, ROA, ROE, WC, CCC

1- Associate Professor IQRA University, email: samina_bahria@hotmail.com

2- Associate Professor IQRA University

3- Associate Professor Jinnah University for women 
IBT Journal of Business Studies Volume 15(1), 2019

\section{INTRODUCTION}

\section{Overview}

The regular concentrate in company back was on the long pull budgetary choices, for example, capital planning, capital structure, and profits. None the less, the enthusiasm for working capital management has expanded amid the most recent two decades, both scholastics and budgetary officers are showing more energy for WC organization. For example, WC organization put into practice were indispensable wellspring of that high ground.WC one great case related to the significance of effectiveness of anorganization's WC administration. They brought up that relative capital arrangement in 1994, yet K-mart had a money revolution period of about 61 days therefore other Mart had a money transforming period of 40 days. Most likely thus, Kmart confronted an extra 2,198.3 million annually in financialcosts. Such proof showed that K-mart weak administration of WC added to it (Nobanee, 2011).

WC management, which includes overseeing money, stock, and records receivable, influences an association's temporary budgetary execution. A few past reviews have measured the effect of WC on firm benefit; WC management has progressively been measured with money change cycle (CCC). Recent researches on CCC have showned its effect on benefit(s) in expansive nations. Be that as it may, Sweden's corporate condition and financial arrangement contrast from multiple different nations. Globally, the Swedish economy can be portrayed as a little, send out arranged open economy with wide spread social advantages subsidized by high charges. The present review investigations the effect of CCC on execution as far as benefit in Swedish SME(s) (Yazdanfar, 2014).

The corporate back writing has customarily centered on the investigation of long haul money related choices. Scientists have especially offered reviews breaking down speculations, capital structure, profits or organization valuation, among different themes. In any case. Truth be told, in the example utilized as a part of the present evaluation, current resources of SME(s) of Spanish firms speak to $69 \mathrm{pc}$ of their benefit(s), and in the period in-between their present liabilities showing more than 52 pc of their liabilities. WC managementis critical due to its concerns for the association(s) profitable and threat, (Smith, 1980). In particular, WC venture included a trade-off between profitableness and threat. Optionsthat tend to enlarge productivity tend to build hazard, and, then again, choices that emphasis on hazard decrease will have a tendency to diminish potential benefit. Gitman opposed that the money change cycle was a key figure WC management. Really, options about the amount to put resources into the client and standard records, and there were ample praise to acknowledge of earners, were resulted in company's money alterationperiod, thatconcluded to no. of days within the date while the companyshould be startedpayment to its providers. Past reviews have measured in light of the money conversioncycle to split down whether limitation this cycle has positive or negative impacts on the company's assistance (Juan, 2007).

\section{Problem Statement}

In real, market imperfections exist and the firm is exposed to many risks including financial distress. Therefore, it is very much needed that the company holds cash to manage the uncertainties. However, the cash level is to be determined after careful analysis so that the company maximizes shareholder wealth and profitability. There are numerous factors that are analyzed while determining optimal level of cash. Therefore, the current study problem statement is to determine the profitability of companies on the back of ROE and ROA. 
IBT Journal of Business Studies Volume 15(1), 2019

\section{Background Objectives and Significance of the Study}

Money is one the most liquid resources and holding trade out a liquid frame implies you have an abnormal state of monetary liquidity and you can pay off essential costs immediately. These costs might be normal or once in a while it might be sudden, that is the reason it is valuable to hold money to meet everyday costs. It additionally gives speculator a mental help that they are sufficiently competent to face instability and crises.

Then again, excess of anything can never be too useful for anybody. Correspondingly, an excessive amount of money is likewise not valuable for any organization. Much measure of money on asset report signals risk onwards. Speculators need to inquire as to why this much measure of cash is not being utilized. The reason for research was mainly to explain the things affecting prosperity KMI-30 Index companies of Pakistan. This makes this study valuable and useful. It will not only add value to the existing literature but it will also open door to more researches.

\section{Outline of the study}

This study was distributed into four separate sections. Section one begun with an introduction of the problem then identifies the need for this research. Hypotheses for research analysis have also been developed in this section. Section two presents review of the published research on the subject and concludes with the identification of areas for research for this project. Section three presents the research methods identified for analyzing the secondary data that is collected for testing the hypotheses and results of this research project while section four discusses the outcome of the research and draws conclusion from the outcome of the research study.

\section{LITERATURE REVIEW}

In this segment, the analysts conduct audit the current writing linking within the duration of money alterationperiod and association's earning ability. A large portion of the consequences of studies that experimentally analyzed the connection between money change cycle and productivity demonstrated a huge and oppositelinkage. Most of a review exhibited basic but negative associations within cash change period and advantage of firms located in Belgian. Likewise, huge negative connection revealed between exchange periods inefficiency of United States companies.

AL Shubiri (2011), contends that assets paying attention on WC can be viewed as concealed sources that can be usedfor improvecompany's financial position. The after-effects of the research of Karaduman, (2011), indicated massivebut negative linkwithin the money change period and benefit estimatedwithearningsfor resources of firmsrecorded on IE.

Affectability in WC management in market flaw, for example, lopsided data, organization clashes or money related pain was analyzed by Caballero (2010). Their outcomes demonstrated that the WC contends with attention in settled capital for an assets of company when it had budgetary limitations. Those findings likewise shown that WC arrangement relies mainly on bartering and other budgetary elements, for example, the accessibility of inside back, financing cost, and accessibility to financial markets. Uyar-(2009), measured the linkage between the money transformation period, benefits of the company and size recorded on Istanbul Exchange. The outcomes demonstrated huge negative connection between the money transformation cycle and benefit, and additionally money CCC and company size. Results showed a lowmoney CCC of the local retail industry other than that of assembling company (Nobanee, 2011). 
Advancing WC limits a company's monetary dangers and enhances its general execution. Therefore, WC assumes a critical part in making firm productivity and intensity. The recent observational outcome confirmed that CCC, intermediary for WC manage, essentially impacts efficiency, and those companies along-with higher CCCs were lower profitable. As normal time frame builds, this was prompt declining firm profitability. A conceivable clarification for the opposite connection amongst CCC and profitability was stretched levels of receivable and stock increment WC along few expenses were required to support the WC. Maintain WC at above from average level would bring about budgetary assets being kept in unfruitful cases (Sharma, 2011). Specifically, our outcomes show that hadaverage CCCs could Enables Company's enhancetheir implementation. The direct factors company size and company age were identified with earning ability also. Main impact of organization size on earnings ability was sure, due to big companies were more valuable firms would probably be high-benefit firms. Expansive, youthful SME(s) with low CCCs were hence more tending to be profitable (Yazdanfar, 2014).

WC management is especially essential on account of little and medium-sized organizations. The majority of these organizations' benefits are as present resources. Additionally, CLwere one of the fundamental well-springs. In this unique condition, the objective of the flow explain to give experimental confirmation about the impacts of WC management on the advantage of an example of SME(s) (Pratap, 2014). A specimen of others firms were utilized to lead an evaluation with board information for SME(s). Information on board of 8872 SMEs were gathered, and covered the duration to 2002 from 1996. Outcomes were like those established in past reviews which were concentrated on huge companies and the examinations did affirm the imperative part of WC management in esteem era in little and medium-sized firms (Mutua, 2014). There is a note-worthy opposite links between SME(s) earnings ability and noof days records stock and receivable days. We can't, withstanding, affirm the quantity of day's records due influences a SME(s) arrival with resources, this connection lost centrality and then we owned for conceivable endo-geneity issues (Juan, 2007).

The diagnostic FAM we have inferred demonstrates that the ROI correspond per versely with the length of the duration of operational WC Different factor manipulate the advent on speculation were the working edge percentage, the settled reserve proportion, the normal devaluation time frame and the remaining term, comprising other current resources and other CL (K., 2002). The impact of CCC on the ROI was principally hard in the modern upkeep benefit area, emerging from light settled resources and great profitableness. Curiously, the CCCs were outstandingly lower period in expansive Finish upkeep benefit endeavors for SME(s) of a similar industry. This implies changed in the CCCs have a considerably huge broad effect on the return-on-investment in extensive upkeep specialist co-ops. The distinction between expansive ventures and SME(s) can be clarified through both settled resources and WC linked economies of degree, \& way that extensive upkeep specialist organizations frequently concentrate on giving managements for the most part to the host organizations. Progressions of the EBITDA in percent influence return-on-investmentvery much that remunerating them. In the arrangement of the process durations of $\mathrm{WC}$ were farfetched within upkeep benefit organizations. Particularly in substantial undertakings the CCC can't be abbreviated. Be that as it may, the expansive undertakings appear to have an upper hand over the SME(s) because of lower settled resources proportions (Marttonen, 2013).

All in all, WC management has critical constructive outcome on market estimation of cited nourishment and refreshments fabricating firms in Nigeria. Money transformation cycle has huge beneficial outcome on market respect; Account congregation period has a note-worthy positive 
outcome on market assessment of quote sustenance and refreshments fabricating firms from Nigeria; Inventory transformation period has long constructive output for market estimation. Payment period has a significant beneficial outcome on market esteem (Dong, 2010). Forceful speculation strategy has noteworthy constructive outcome on market estimation of nourishment and refreshments producing firms in Nigeria. This review in this way reasons sustenance and drinks producing firms in Nigeria can't augment its benefit and in addition shareholders' riches without giving careful consideration to the management of the different segments of its WC. It is recommended that more endeavors ought to be coordinated at forceful advertising in order to lift deals and thusly increment profitableness and additionally showcase estimation of nourishment and refreshments fabricating firms in Nigeria. Likewise, these organizations ought to move from direct venture strategy to forceful speculation approach. This progression will enhance the execution of firms in this segment (Ademola, 2014).

This showed more profitable companies were less propelled to treaty with their WC (ALShubiri, 2011). Explanation of such positive linkages possibly dissatisfactionin the market to stagnant those companies with in extravagant management of WC. Notwithstanding the way that theorists in the cash related markets comprehended that associations arranging and sharpening capable administration for their WC justify more regard, not sufficient reaction seen the budgetary market which was given confirmation of basic off-putting association within market valuation of firm and the money change cycle. Above audit was basic approach, makers and controllers who needed to shift and urge executives and stakeholders to give watchful thought for WC from side to side upgrading examiners' careand improved straight (Abuzayed, 2012).

The management of trade exchanges out the organizations is vital in commitment of the segment of back, which is endeavoring to clasp the amicability among danger and in a shape that endeavors for planning assets along-withCL as it was triedby corporate trade arrangement out a viable way predictable with the organization's arrangements as for receivables, payablesand stocks. The consequences of this assessment showed that there is literally note-worthy and positive linkage between money conversion cycle and factors, in particular: obligation, showcase, efficiency, liquidity and profits, marker at critical level of 1 pcand $5 \mathrm{pc}$; and the size indicator was without power association with massive level of 10 pcand there wasno big association with efficiency and money conversion cycle (Jinadu, 2010). This examination concluded that what occurred in the around the globe budgetary urgencyand that was one of the reason indecisive advances and the missing of make sure, which encouraged the dissatisfaction and quite the market, while few banks have extended this worldwide money related urgency to outside nations and Arabic, which identifies with these nations remote contributed. This impact relies on upon the sum sovereign riches store of the State in those nations influenced by the worldwide money related emergency concerning Jordan is viewed as the budgetary division is solid and has a high liquidity, which thought about emphatically mechanical organizations by providing them leverage and there were strapping measures by national bank as a controller executes and screened oversees leverage operations regarding to the sort and volume is in like manner, those businesses were working with banks to secure pledge in excess of the size of leverage had for that this was a positivity for the banks. So here we induced that span of collision in Jordan was very low in overall budgetary catastrophe and these were a comparative reducing of interests in a couple of durations, yet these vogue in times within different organizations in view of methods of banks in fence increment the giving of leverage end bank but may be mental collision. Most of the experts recommended to the necessity for associations to change the inward plans of the social occasion, stock \& portion \& revive those measured relying upon economic situations and rivalry. Additionally, there is adequate adaptability to manage clients of different kinds (Al-Shubiri, 2013).

\section{Page $\mid 88$}


The goal of the review was to explore the relative consequence of WC management, considered with money conversion cycle (CCC) and its parts to the profitableness of AIM recorded SME(s). The review depended on a board information relapse investigation of the money related information of $133 \mathrm{SME}(\mathrm{s})$ over a 5year time period (2005-2009) and response from 19 out of same 133 recorded SME(s) which were reacted to the survey study. The outcome from the board information relapse examination recommends that $\mathrm{A} / \mathrm{c}$ payable $\& \mathrm{~A} / \mathrm{c}$ receivable were basic for the productivity of SME(s). Stock (Inventory) and CCCs were watched not basic. The judgment that both A/c payable\& $\mathrm{A} / \mathrm{c}$ receivable were basic benefit of $\mathrm{SME}(\mathrm{s})$ is unsurprising with revelations. On the other hand, the poll review comes about demonstrate that in spite of the fact that the management of WC and anyone of its parts (AR, AP and INV) was critical, the management of AR is fairly more importantthan AP for the profitability of $\operatorname{SME}(\mathrm{s})$. In interpret the outcomes; be that as it may, a few constraints should be noted. To start with, our review is restricted to 133 AIM recorded SME(s), and along these lines the discoveries can't be summed up to all organizations. Second, our poll overview reaction rate is low at 14.3 for every penny in spite of the fact that it is tantamount to other reaction rates for $\operatorname{SME}(\mathrm{s})$.

Notwithstanding the impediments, taken generally speaking, these outcomes have suggestions, both the SME(s) and future researchon the comparative magnitude of WC arrangement \& its divisional benefits. To start with, the outcomes werethe first to record the comparative significance of WC and its divisionto $\mathrm{SME}(\mathrm{s})$ benefit. The comparative importance of WC and its segments to benefit is possibly important for the management of SME(s) who has constrained assets and might be need the management of those WC division that were more important to the SME(s) profitableness.

On the other hand, the conflicting findings in this regard of comparative importanceof AP and AR suggest that there wasa requirement for further studyto set up which of the divisionwas fairly more importantfor SME(s) efficiency. Despite the fact that the outcomes are uncertain with respect to whether AP or AR was fairly more essential than whether CCCs or INV led to the final conclusion which was provided the SME(s) inhibited assets, they have to needed their WC by concentrating on AP and AR to improve profitability (Tauringana, 2013).

\section{Hypotheses}

1. CCC has significant impact on ROA

2. Debt-to-assets ratio has significant impact on the ROA

3. Firm size has significant impact on the ROA.

4. WC has significant impact on the ROA

5. CCC has significant impact on ROE

6. Debts to assets ratio has significant impact on the ROE

7. Firm size has significant impact on the ROE

8. WC has significant impact on the return on equity

9. CCC has significant impact on Tobin's Q

10. Debts to assets ratio has significant impact on the Tobin's Q

11. Firm size has significant impact on the Tobin's $Q$

12. WC has significant impact on the Tobin's Q 
IBT Journal of Business Studies Volume 15(1), 2019

\section{RESEARCH METHODOLOGY}

\section{Method of Data Collection}

This segment explained the processof data collection. There are two main techniques to collect data i.e. primary and secondary data. The secondary data for this research work was collected from firms accounting books. Balance sheet and Statement of comprehensive Income was studied to gather data of listed companies in the KMI-30 Index. After collecting data from financial statements of various companies, variables were calculated in order to analyze data.

\section{Sampling Technique}

The sampling estimationwas the method through which the research selects the sample from the population. In this research the non-probability convenience sampling technique was used to collect data of KMI-30 Index.

\section{Sample Size}

5 years data is collected from 30 companies listed in the KMI-30 Index.

\section{Instrument of Data Collection}

Financial statements of KMI-30 Index companies were collected from published sources. Average INV days, average AR days, average AP days, current assets, current liabilities, ROA, Tobin's Q and ROE.

\section{Research Model Developed}

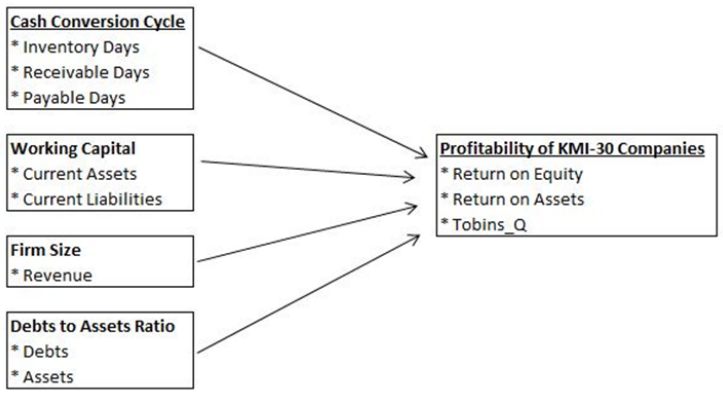

This above mentioned model was used to calculate the variables and few formulas used to calculate these above mentioned variables:

- CCC: Inventory days + ARDays-APdays

- Average Account receivables collection period: Account receivables*365/sales

- Average inventory days: Inventory*365/ credit sales

- Accounts payables period: AP *365/ COGS

- Firm Size: NL (Natural Logarithm) of sales

- WC: Current assets/Current liabilities

- ROE: Net Income/ S.H.E

- ROA: Earnings /TA (Total Assets)

- Tobin's Q: Total MV (Market Value) of firm/TA 


\section{Statistical Technique}

In this research, regression test which was statisticalestimation used to examine the independent variable impacts on dependent variable through independent variables i.e. ROA, ROE and Tobin'sQ.

\section{Empirical Results}

Entire data was collected from the annualaccountsof companies werelisted in KMI-30 Index. The results from regression analysis (Table 4.1) showed the importanceof the variable(s). Table indicated that the values of probability of variables less than 0.05 have significant impact on dependent variables of the companies listed in KMI-30 Index and values greater than 0.05 does not impact companies listed in KMI-30 Index. This research revealed that CCC, debts to assets ratio were significantly impacted on the fertility of the company which was estimated by the ROE, ROA and Tobin's Q, rest of the variables were not that much impacted on the dependent variables as per statistical test applied. WC would be impacted on the company's profitability which was listed in the KMI-30 Index. Many companies were focusing on their CCC and trying really hard to keep in the optimum level or with equivalent to industry. Managing WC was playing a vital role in the company because it helped companies in their smooth operations. If company unable to manage its WC so it led to disaster for the company image, lack of product availability in the market due to lack of funds available to the company to manage its day to day operations. Therefore, companies putting more efforts to manage its CCC which helped to keep current ratio and quick ratio in line with industry averages. Debts to assets ratios were also impacted on the ROA and ROE and Tobin's Q and companies were trying to low debts to assets ratio which would be a good sign for the health of the company. Results disclosed that five variables were accepted while other variables were rejected on that basis concluded that 1) CCChas significant impacted on the ROA, and ROE, 2) Debts to assets ratio having significant impact on return on assets and return on equity and Tobin's Q.

\subsection{Hypothesis Assessment Summary}

\begin{tabular}{|l|l|l|l|}
\hline Sno. & Hypothesis(es) & Sig Value & Empirical Conclusion \\
\hline H1 & $\begin{array}{l}\text { CCC has significant impact on return on } \\
\text { assets }\end{array}$ & -2.826441 & Accepted \\
\hline H2 & $\begin{array}{l}\text { Debts-to-assets ratio has significant impact } \\
\text { on the ROA }\end{array}$ & -5.598312 & Accepted \\
\hline H3 & $\begin{array}{l}\text { Firm size has significant impact on the } \\
\text { ROA }\end{array}$ & -0.166310 & Rejected \\
\hline H4 & WC has significant impact on the ROA & 0.683026 & Rejected \\
\hline H5 & CCC has significant impact on ROE & -3.128785 & Accepted \\
\hline H6 & $\begin{array}{l}\text { Debts-to-assets ratio has significant impact } \\
\text { on the ROE }\end{array}$ & -2.584618 & Accepted \\
\hline H7 & Firm size has significant impact on the ROE & 0.767384 & Rejected \\
\hline H8 & WC has significant impact on the ROE & 0.261621 & Rejected \\
\hline H9 & CCC has significant impact on Tobin's Q & -1.477524 & Rejected \\
\hline H10 & $\begin{array}{l}\text { Debts-to-assets ratio has significant impact } \\
\text { on the Tobin's Q }\end{array}$ & -3.293579 & Accepted \\
\hline H11 & $\begin{array}{l}\text { Firm size has significant impact on the } \\
\text { Tobin's Q }\end{array}$ & -0.386265 & Rejected \\
\hline H12 & WC has significant impact on the Tobin's Q & -0.026331 & Rejected \\
\hline
\end{tabular}


IBT Journal of Business Studies Volume 15(1), 2019

\section{CONCLUSION, POLICY IMPLICATION AND FUTURE RESEARCH}

After closed examination of the variables in this research come up with the conclusion of CCC and WC has note-worthy impact on the profitability of company. Companies with sound earnings are less concerned with the issues of $\mathrm{WC}$, while those companies which were managing a longer CCC, they likely to face the liquidity problem that negatively impacted on the profitability and also face difficulty in managing WC. Increasing WC requirement also increased the financial cost of the company. Therefore, companies tried as much as they can to reduce the CCC and increase its internal generated earnings through which they can finance their operations.

\section{Policy Implications}

It was recommended to the companies of listed in the KMI-30 to maintain the CCC at their minimum level or in lines with the industry norms, so they can avoid the liquidity problem along with the reduce the shortfall of cash requirement which were needed to smoothly run the operations of the companies.

\section{Future Research}

In future, new researches should discover the effects of cash holding on firm's performance. Future researches should continue to discover the reasons why growth opportunities and debt ratios are insignificant for excessive cash holdings. Moreover, few researches have been done in this regard and needs more concentration of researchers so that it can be explored.

\section{REFERENCE}

Abuzayed, B. (2012). Working capital management and firms' performance in emerging markets: the case of Jordan. International Journal of Managerial Finance, 8 (2), 155-179.

Ademola, O. (2014). The Effect of Working Capital Management on Market Value of Quoted Food and Beverages Manufacturing Firms in Nigeria. International Journal of Business and Social Science, 8 (1), 168-177.

ALShubiri, F. N. (2011). The effect of working capital practices on risk management: Evidence from Jordan. Global Journal of Business Research, 5 (1), 39-54.

Al-Shubiri, F. (2013). The relationship between cash conversion cycle and financial characteristics of industrial sectors: an empirical study. Investment Management and Financial Innovations, $10(4), 95-102$.

Dong, H. (2010). The relationship between working capital management and profitability: a Vietnam case. International Research Journal of Finance and Economics, 5 (49), 59-67.

Jinadu, O. (2010). An Appraisal of the relationship between working capital and liquid assets of Nigerian Companies: A comparative study of ten selected companies. Journal of Research in National Development, 8 (1), 7-15.

Juan, P. (2007). Effects of working capital management on SME profitability. International Journal of Managerial Finance, 3 (2), 164-177.

K., K. (2002). A cost model of industrial maintenance for profitability analysis and benchmarking. International Journal of Production Economics, 79 (1), 15-31.

Marttonen, S. (2013). Profitable working capital management in industrial maintenance companies. Journal of Quality in Maintenance Engineering, 19 (4), 429-446.

Mutua, D. (2014). An empirical analysis of the determinants of the cash conversion cycle in Kenyan listed non-financial firms. Journal of Accounting in Emerging Economies, 4 (2), 175-196.

Nobanee, H. (2011). Cash conversion cycle and firm's performance of Japanese firms. Asian Review 
of Accounting, 19 (2), 147-156.

Pratap, H. (2014). Working capital management: a literature review and research agenda. Qualitative Research in Financial Markets, 6 (2), 173-197.

Sharma, A. (2011). Effect of working capital management on firm profitability: empirical evidence from India. Global Business Review, 12 (1), 159-173.

Tauringana, V. (2013). The relative importance of working capital management and its components to SME(s)' profitability. Journal of Small Business and Enterprise Development, 20 (3), 453469.

Yazdanfar, D. (2014). The impact of cash conversion cycle on firm profitability : An empirical study based on Swedish data. International Journal of Managerial Finance, 10 (4), 442-452.

\section{APPENDIX}

Table 4

Return on Assets

\begin{tabular}{|c|c|c|c|c|}
\hline $\begin{array}{l}\text { Dependent Variable: ROA } \\
\text { Method: Panel Least Squares } \\
\text { Sample: } 20102014 \\
\text { Periods induded: } 5 \\
\text { Cross-sections included: } 30 \\
\text { Total panel (balanced) observati }\end{array}$ & ons: 150 & & & \\
\hline Variable & Coefficient & Std. Error & t-Statistic & Prob. \\
\hline CASH_CONVERSION_CYCLE & -0.000634 & 0.000224 & -2.826441 & 0.0054 \\
\hline $\begin{array}{l}\text { DEBT_TO_ASSETS_RATIO } \\
\text { FIRM_SIZE }\end{array}$ & $\begin{array}{l}-0.212621 \\
-7.17 \mathrm{E}-09\end{array}$ & $\begin{array}{l}0.037980 \\
4.31 \mathrm{E}-08\end{array}$ & $\begin{array}{l}-5.598312 \\
-0.166310\end{array}$ & $\begin{array}{l}0.0000 \\
0.8681\end{array}$ \\
\hline WORKING_CAPITAL & $\begin{array}{l}3.43 E-08 \\
0.230984\end{array}$ & $\begin{array}{l}5.03 E-08 \\
0.024666\end{array}$ & $\begin{array}{l}0.683026 \\
9.364412\end{array}$ & $\begin{array}{l}0.4957 \\
0.0000\end{array}$ \\
\hline R-squared & 0.213865 & Mean depen & nt var & 0.089095 \\
\hline Adjusted R-squared & 0.192179 & S.D. depend & tvar & 0.117258 \\
\hline S.E. of regression & 0.105391 & Akaike info $\mathrm{cr}$ & erion & -1.629522 \\
\hline Sum squared resid & 1.610540 & Schwarz crite & & -1.529168 \\
\hline $\begin{array}{l}\text { Log likelihood } \\
\text { F-statistic }\end{array}$ & $\begin{array}{l}127.2142 \\
9.861694\end{array}$ & $\begin{array}{l}\text { Hannan-Quir } \\
\text { Durbin-Wats }\end{array}$ & $\begin{array}{l}\text { criter. } \\
\text { stat }\end{array}$ & $\begin{array}{r}-1.588751 \\
0.670664\end{array}$ \\
\hline Prob(F-statistic) & 0.000000 & & & \\
\hline
\end{tabular}

Table 4.1

Return on Equity

\begin{tabular}{|c|c|c|c|c|}
\hline \multicolumn{5}{|c|}{$\begin{array}{l}\text { Dependent Variable: ROE } \\
\text { Method: Panel Least Squares } \\
\text { Sample: } 20102014 \\
\text { Periods induded: } 5 \\
\text { Cross-sections induded: } 30 \\
\text { Total panel (balanced) observations: } 150\end{array}$} \\
\hline Variable & Coefficient & Std. Error & t-Statistic & Prob. \\
\hline CASH_CONVERSION_CYCLE & -0.001546 & 0.000494 & -3.128785 & 0.0021 \\
\hline $\begin{array}{c}\text { DEBT_TO_ASSETS_RATIO } \\
\text { FIRM_SIZE }\end{array}$ & $\begin{array}{r}-0.216332 \\
7.29 \mathrm{E}-08\end{array}$ & $\begin{array}{l}0.083700 \\
9.50 \mathrm{E}-08\end{array}$ & $\begin{array}{r}-2.584618 \\
0.767384\end{array}$ & $\begin{array}{l}0.0107 \\
0.4441\end{array}$ \\
\hline WORKING_CAPITAL & $\begin{array}{l}2.90 E-08 \\
0.330931\end{array}$ & $\begin{array}{l}1.11 E-07 \\
0.054360\end{array}$ & $\begin{array}{l}0.261621 \\
6.087790\end{array}$ & $\begin{array}{l}0.7940 \\
0.0000\end{array}$ \\
\hline R-squared & 0.101078 & \multicolumn{2}{|c|}{ Mean dependent var } & 0.162525 \\
\hline Adjusted R-squared & 0.076280 & \multicolumn{2}{|c|}{ S.D. dependent var } & 0.241661 \\
\hline S.E. of regression & 0.232261 & \multicolumn{2}{|c|}{ Akaike info criterion } & -0.049141 \\
\hline Sum squared resid & 7.822077 & \multicolumn{2}{|c|}{ Schwarz criterion } & 0.051213 \\
\hline Log likelihood & 8.685603 & \multirow{2}{*}{\multicolumn{2}{|c|}{$\begin{array}{l}\text { Hannan-Quinn criter. } \\
\text { Durbin-Watson stat }\end{array}$}} & -0.008371 \\
\hline F-statistic & 4.076062 & & & 0.882805 \\
\hline Prob(F-statistic) & 0.003676 & & & \\
\hline
\end{tabular}


IBT Journal of Business Studies Volume 15(1), 2019

Table 4.2

Tobins_Q

\begin{tabular}{|c|c|c|c|c|}
\hline \multicolumn{5}{|c|}{$\begin{array}{l}\text { Dependent Variable: TOBINS_Q } \\
\text { Method: Panel Least Squares } \\
\text { Sample: } 20102014 \\
\text { Periods induded: } 5 \\
\text { Cross-sections included: } 25 \\
\text { Total panel(unbalanced) observations: } 122\end{array}$} \\
\hline Variable & Coefficient & Std. Error & t-Statistic & Prob. \\
\hline CASH_CONVERSION_CYCLE & -0.009542 & 0.006458 & -1.477524 & 0.1422 \\
\hline $\begin{array}{c}\text { DEBT_TO_ASSETS_RATIO } \\
\text { FIRM_SIZE }\end{array}$ & $\begin{array}{l}-3.726470 \\
-4.53 E-07\end{array}$ & $\begin{array}{l}1.131435 \\
1.17 \mathrm{E}-06\end{array}$ & $\begin{array}{l}-3.293579 \\
-0.386265\end{array}$ & $\begin{array}{l}0.0013 \\
0.7000\end{array}$ \\
\hline WORKING_CAPITAL & $\begin{array}{r}-3.54 \mathrm{E}-08 \\
3.552609\end{array}$ & $\begin{array}{l}1.35 \mathrm{E}-06 \\
0.705467\end{array}$ & $\begin{array}{r}-0.026331 \\
5.035828\end{array}$ & $\begin{array}{l}0.9790 \\
0.0000\end{array}$ \\
\hline $\begin{array}{l}\text { R-squared } \\
\text { Adiusted R-squared }\end{array}$ & $\begin{array}{l}0.105601 \\
0.075023\end{array}$ & \multicolumn{2}{|c|}{ Mean dependent var } & $\begin{array}{l}1.136781 \\
2.921719\end{array}$ \\
\hline $\begin{array}{l}\text { S.E. of regression } \\
\text { Sum squared resid }\end{array}$ & $\begin{array}{l}2.809984 \\
923.8333\end{array}$ & \multicolumn{2}{|c|}{ Akaike info criterion } & $\begin{array}{l}4.944355 \\
5.059274\end{array}$ \\
\hline $\begin{array}{l}\text { Log likelihood } \\
\text { F-statistic }\end{array}$ & $\begin{array}{r}-296.6056 \\
3.453524\end{array}$ & \multicolumn{2}{|c|}{$\begin{array}{l}\text { Hannan-Quinn criter. } \\
\text { Durbin-Wats on stat }\end{array}$} & $\begin{array}{l}4.991031 \\
1.506134\end{array}$ \\
\hline Prob(F-statistic) & 0.010485 & & & \\
\hline
\end{tabular}

